\title{
6
}

\section{The girls return}

Doug Nicholls - Aboriginal activist, pastor, Australian Rules football star for Fitzroy, and Governor of South Australia - was eight years old in 1914. At the time he was living on Cumeroogunga Station on the New South Wales side of the Murray River and it was then that he had the 'fear of the police instilled in him'. ${ }^{1}$ As a young lad he knew nothing of the world outside Cumeroogunga Station nor did he understand that there were different laws for Aboriginal people and white people. He does remember though how the police would come to the station 'at night, or at odd times looking under the beds and behind the sheds for those who were meant to be ... living among the white people'. He soon understood that 'all half castes or less, over fourteen years, must leave the reserves'; they were no longer eligible for rations and had to make their way in the white community. As an eight-year-old he learned something else: the police were after his 16-year-old sister Hilda. Anticipating trouble, the manager of Cumeroogunga Station had organised for all the Aboriginal men to leave early in the day, to cut timber. When the men were gone, two police cars arrived. Doug, standing at a distance on an elevated position with other youngsters ready for school, watched a policeman push open the door of his mother's home, enter unannounced and emerge

1 Clark, The Boy from Cumeroogunga, 31. Jack Horner refers to this incident in Bill Ferguson, 13. Horner puts the date at 1918, whereas Clark puts it at 1914 (Doug Nicholls was born in 1906 and, according to Clark, the incident took place when he was eight in 1914). There was a lot of unrest at Cumeroogunga around 1918-19: a riot had occurred at Barmah when a policeman tried to shoot at a group of Aboriginal men, an outbreak of influenza resulted in heavy restrictions on the Aboriginal community's ability to move about and there was deep unrest about the taking of girls from the station by the Board. The school teacher, Thomas James, had written several letters to the Education Department, and in April 1919 he telegrammed: 'No attendance today police seized some girls parents with children fled across river situation serious'; see Davis, Australian Settler Colonialism, 35-37. 
dragging his sister Hilda firmly by the hand. His mother, Florence, ran after them protesting loudly: 'You can't take her!' The policeman shouted that he was, and if she did not stop her 'caterwauling' he would 'take all her kids'. Florence turned quickly in Doug's direction and screamed: 'Run, Dougie, run!'2

The two police cars left with six girls, along with Hilda's mother who had whacked the policeman with a wooden stake and fought her way into the car with the girls only to be bundled out 20 kilometres up the road to walk home. The Cumeroogunga community spoke of the events for 'days and weeks and months and years afterwards'. Doug knew the adults were 'angry and afraid'. He didn't understand what had happened; but he knew 'that the police had frightened his mother, taken his sister and threatened to take him'. ${ }^{3}$

The Board's prosecution of the removal of young Aboriginal girls and boys from the camps, reserves and stations has been extensively discussed and written about over the last three decades. In his speech to the parliament, prime minister Kevin Rudd acknowledged and apologised for the removal policies that were enforced across all of Australia. Rudd spoke to the nation:

We apologise for the laws and policies of successive parliaments and governments that have inflicted profound grief, suffering and loss on these our fellow Australians.

For the pain, suffering and hurt of these stolen generations, their descendants and for their families left behind, we say sorry.

To the mothers and the fathers, the brothers and the sisters, for the breaking up of families and communities, we say sorry. ${ }^{4}$

Rudd's words broke a long period of silence; the previous federal government under John Howard had been unable to say 'sorry' for 11 years (and still refuses to this day).

In 1916, there were no such regretful sentiments from the Board for the parlous position of many Aboriginal people across the state of New South Wales. The policies directed at Aboriginal people had hardened during

2 Clark, The Boy from Cumeroogunga, 33.

3 Clark, The Boy from Cumeroogunga, 35.

4 Quoted in Raynes, The Last Protector, ix. 
the first decade of the twentieth century with the passing of the Aborigines Protection Act 1909, but in the second decade of the century the Board had entered a new phase. Inspector Robert Donaldson, and colleague A.L. Swindlehurst, freed from the regular Board meetings, were able to travel across the state and identify Aboriginal girls and boys suitable for training. These were sent to the Cootamundra Training Home for Girls, to the Kinchela Home for boys on the Macleay River (from 1924) or directly into service.

\section{The Stolen Generations}

Aboriginal child removal in New South Wales is now a well-told story. ${ }^{5}$ The Stolen Generations has become part of the Australia's historical consciousness since historian Peter Read coined the term in 1981 and produced a pamphlet for the New South Wales Ministry of Aboriginal Affairs. ${ }^{6}$ Read estimated that in New South Wales between 1883 and 1969 some 5,625 children were removed from their families. ${ }^{7}$ In a later publication, A Rape of the Soul so Profound, he revised the figures to an estimate of $10,000 .{ }^{8}$ Read's estimates have been challenged - along with the works of other well-known Australian historians - by journalist Keith Windschuttle in his third volume of The Fabrication of Aboriginal History. ${ }^{9}$ Windschuttle claims that Read, in his first analysis of removals from New South Wales in 1981, had exaggerated some estimates, inflated figures and double counted. He revised Read's assessment of 5,625 down to 2,600. ${ }^{10}$ Windschuttle contests that the whole concept of the Stolen Generations is totally unwarranted and that 'Aboriginal children were never removed from their families in order to put an end to Aboriginality or, indeed, to serve any improper government policy or

5 There are several volumes that depict the stories of those removed. Mellor and Haebich, eds, Many Voices; Human Rights and Equal opportunity Commission (HREOC), Bringing Them Home; Edwards and Read, eds, The Lost Children; Read, 'Fathers and Sons'; Read, 'A Rape of the Soul so Profound', 23-33; Simon, Through My Eyes; Tucker, If Everyone Cared; Haskins, One Bright Spot; Miller, Koori: A Will To Win; Rintoul, The Wailing; Woodrow, One of the Lost Generation; Clark, The Boy from Cumeroogunga; and Matthews (as told to), The Two Worlds of Jimmie Barker.

6 Read had initially used the term 'The Lost Generations', but Jay Arthur, according to Read, proposed The Stolen Generations'. See Windschuttle, The Fabrication of Aboriginal History, 73.

7 Windschuttle, The Fabrication of Aboriginal History, 61. Read revised that figure to 6,225 in The Stolen Generations, 11.

8 Read, A Rape of the Soul so Profound, 27.

9 Windschuttle, The Fabrication of Aboriginal History.

10 Windschuttle, The Fabrication of Aboriginal History, 102. 
program'. ${ }^{11}$ This became part of a heated debate at the highest level of politics, which began with the 'History Wars'. ${ }^{12}$ Windschuttle escalated the discussion in a determined attack on many historians in the field of Aboriginal history. His first volume, which challenged the claims made by historians of the Australian frontier wars, was heavily criticised, primarily in Robert Manne's publication of Whitewash: On Keith Windschuttle's Fabrication of Aboriginal History. ${ }^{13}$ Windschuttle's third volume on the Stolen Generations 1881-2008 has not been rebutted in the same way. Historian Bain Attwood has some suggestions as to why this may be so. Attwood offers several ways to respond to Windschuttle, one of which is not to! Attwood argues that Windschuttle's work 'is a form of denialism' and historians should not 'engage in such work' because 'seeking to rebut' his work only draws attention to it. ${ }^{14}$ Attwood contends that the 'truth' for Windschuttle is not a complex or complicated affair: 'Truth is black or white; there are no greys'. He argues that Windschuttle does not make 'fine distinctions' but reduces 'historical truth' to a 'matter of facts' and that when historians claim 'a truth' based upon 'interpretation and perspective', Windschuttle feels as though he has been 'misled' or even 'duped'. ${ }^{15}$ Windschuttle's simplistic views on the truth and history are challenged below with his assertions concerning the removal of Aboriginal children.

Peter Read laments the fact that old established ground still needs to be defended. He argues that historical research should instead be breaking new boundaries and deepening our understanding of the impact upon Indigenous Australians by the various jurisdictions that controlled their lives. ${ }^{16}$ Read contends that there are 'larger' and 'smaller' truths in history. For example, in the Australian colonial context, a 'larger truth' is the dispossession of Aboriginal people by the British resulting in the deaths by frontier violence of - according to Henry Reynolds - up to 30,000

11 Windschuttle, The Fabrication of Aboriginal History, 17.

12 Attwood, Telling the Truth about Aboriginal History, is essential reading regarding the 'History Wars'; Mark McKenna provides an instructive background to the development of the 'Black Armband' view of Australian history (a term first coined by Professor Geoffrey Blayney) and canvasses the proponents on both sides of the argument. See McKenna, 'Different Perspectives on Black Armband History'.

13 Manne, ed., Whitewash.

14 Attwood, Telling the Truth about Aboriginal History, 3-4.

15 Attwood, Telling the Truth about Aboriginal History, 69.

16 Read, 'Clio or Janus?', 54-60. 
Aboriginal people. ${ }^{17}$ Over time, historians wrote of 'smaller truths'; for example, that some Aboriginal people 'betrayed or led neighbouring clans to their deaths, that some pastoralists protected bush people against their neighbours [and] that some Aboriginal people committed massacres of their own'. At the same time, other historians reinforced the central truth of dispossession with examples supporting the 'big' truth. Read argues that these 'local qualifications, of which there were many, did not seem to disturb the central fact of dispossession-by-violence'. ${ }^{18}$

Read's thesis is pertinent in the context of exploring child removals. The important 'big truth' was the fact that Aboriginal children in New South Wales were removed from families in vastly increased numbers after 1916. They were targeted because they were Aboriginal and particularly if they were 'half-castes', 'quadroons' or 'octoroons'. However, by 1995 Read had decided not to write any further of those who had been separated because the previous 20 years had produced 'volumes of oral testimony', 'blanket media coverage' and extensive postgraduate research, so that the Stolen Generations had 'become part of the fabric of Australian history'. It was now time to research or write about the qualifications, the regional variations, the 'smaller truths'. Smaller truths included stories of some Aboriginal children who received a good education and loved their white parents, of some Aboriginal parents who had abandoned their children or of others still who asked the Board to look after their children. Other 'small truths' include the fact that Aboriginal mothers had a 'blanket thrown over their legs in childbirth to prevent them seeing their babies even once', that 'hardly anyone from the Kinchela Boys Home reached the age of fifty-five', and that 'officials looked forward to the day when there would be no identifying Aboriginals remaining in the whole of southern Australia. But Read argues these histories cannot be told if the central truth is continually challenged. The quandary for the historian, Read suggests, is 'how can we tell little truths if the big truth is so under attack that its future in the mainstream narrative is imperilled?' 19

17 Reynolds, The Forgotten War, 134. The figure of 30,000 is a revision of his earlier work The Other Side of the Frontier, 121. To calculate the numbers of Aboriginal people who died in the conflict, Reynolds considers the estimates by Ryan in Tasmania (800), Green in one area of Western Australia (102), Prentis in the Northern Rivers region of NSW (100), Christie in Victoria $(2,000)$ and Reynolds in Queensland (between 8,000 and 10,000). Reynolds made an educated assessment: for the "continent as a whole it is reasonable to suppose that at least 20,000 Aborigines were killed as a result of conflict with settlers' and that 'somewhere between 2,000 and 2,500 Europeans in the course of the invasion and settlement of the continent' died (121-22).

18 Read, 'Clio or Janus?', 54-55.

19 Read, 'Clio or Janus?', 56-59. 
The declared objectives of the Aboriginal Protection Board (APB) were to remove Aboriginal children from the influence of their communities, to train them as domestic servants, to take their place in mainstream Australia as part of the labouring classes, and for them never to return to their families or communities. The corollary is that Aboriginal families lived in constant fear of losing their children. The exact number removed is important but will never be known precisely - yet not knowing does not displace the 'larger' truth of systematic removal. Intellectual endeavour and intelligent estimation allow some conclusions to be drawn. ${ }^{20}$

\section{The Board's intentions and the identification for removal}

As noted, the removal of Aboriginal children from their families and placement in apprenticeships had been in the mind of the Board since $1883 .{ }^{21}$ Fosbery and King had advocated the same in their 1883 report to the colonial secretary on the Maloga and Warangesda missions. Their recommendation to first target only those children without parents and then to consult with the parents so as to obtain their consent suggests a modicum of understanding of the severity of the policy. The report also acknowledged that the feelings of the parents and relatives should be taken into consideration. ${ }^{22}$ There were no such niceties from 1916.

\section{The focus on the girls}

As revealed in Chapter 4, Robert Donaldson and the Board had convinced the colonial secretary that those children with a less than half of an 'admixture of Aboriginal blood' needed to be removed from the camps, reserves and stations. Although both sexes were targeted for removal, the policy focused strongly on girls. This is demonstrated by the fact that Cootamundra Training Home for girls was established in 1912,

20 Reynolds, The Other Side of the Frontier, 121.

21 Aboriginal child removals had, of course, occurred well before the Board existed. Richard Johnson, the chaplain on the First Fleet, and his wife Mary, took in a young Aboriginal girl named Araboo in 1789: see Harris, One Blood, 41. In 1814, Lachlan Macquarie's Native Institution removed Aboriginal children from their communities: see Harris, One Blood, 52.

22 Aboriginal Mission Stations at Warangesda and Maloga (Report on Working Of.), New South Wales Legislative Assembly, 18 January 1883, 4. 
well before an equivalent home for boys at Kinchela in 1924. ${ }^{23}$ Moreover, Heather Goodall's research shows that from 1912 to 1921, '81 per cent of the children removed were girls' and for the whole period up to 1928, 'girls made up 72 per cent of all the 12 and over children who were taken'. ${ }^{24}$ All 'half-caste', 'quadroon' and 'octoroon' boys were required to leave the stations and reserves to find work, while the girls at the same age had either to accept domestic work or be taken to Cootamundra Training Home.

The Board's unequivocal policy on the removal of girls, as adopted on 6 April 1916, stated:

All girls on reaching the age of 14 years ... shall leave the Reserves. In order to affect this result, the mothers shall be given the option and opportunity of themselves placing their girls out in situations to the satisfaction of the Board's Officers. If they fail to do this within a period of one month, after being notified, the Board's Inspectors shall have power to despatch such girls to Sydney or to Cootamundra Home for a period of training, as arranged by the Secretary. ${ }^{25}$

It was not a question of neglect or having no parents; the APB compelled all mixed-race girls, regardless of their circumstances, to leave. The month's grace given to the parents to find a placement for their female children could be viewed, at worst, as an exercise in saving the Board's time and resources or, at best, a weak attempt to allow girls to be placed at a location of her or her parents' choosing. It was no coincidence that the identification process began at age 14 . Goodall argues that the apprentice system was 'quite explicitly directed at removing girls reaching puberty from the Aboriginal community'. The intention was to 'intervene in the rising Aboriginal birth-rate by constricting and controlling young, fertile Aboriginal women's sexual activity. ${ }^{26}$

The Board had two clear and related objectives: to hasten the closure of the stations and reserves; and to 'absorb' all Aboriginal girls of marriageable age into white society. Katherine Ellinghaus contends that politicians, in the south-eastern states, 'tried to engineer the "disappearance" of

23 Cole, 'The Glorified Flower', 65.

24 Goodall, 'Assimilation Begins in the Home', 81-82.

25 APB Minutes (hereafter $A P B M$ ), 6 April 1916, Item 1. All APBM accessed via: Minute Books (Aborigines Welfare Board), NRS 2, NSW Department of Aboriginal Affairs, Sydney.

26 Goodall, 'Assimilation Begins in the Home', 81. 
their Indigenous populations by physically dividing Aboriginal people from one another, removing families and individuals from reserves, and removing children from their families'. ${ }^{27}$ Ellinghaus suggests that New South Wales was unique in its 'blatant and single-minded focus on absorbing the Aboriginal population by means of removing children from their parents'. ${ }^{28}$ Victoria Haskins declares that, through the apprentice system, the APB intended to reduce the numbers within the reserves and stations to bring about their eventual closure and - moreover - to 'breed out the race' ${ }^{29}$ Her conclusion is chilling:

The New South Wales Aborigines Protection Board colluded in, condoned and indeed encouraged the systematic sexual abuse and impregnation of young Aboriginal women in domestic apprenticeships with, I contend, the ultimate aim of eradicating the Aboriginal population. ${ }^{30}$

The Board's language was circumspect. It did not use words such as 'breeding out', 'intervening in the birth rate', 'engineering' or 'eradicating', but its intent was the same. It frequently used the terms 'merging' and 'absorption' coupled with the belief that the 'full-blood' population would soon die out; the unstated conclusion was that the Aboriginal 'problem' would soon be solved.

To strengthen the argument that the Board's intent was to 'breed out the race', Haskins explains that the apprenticing of white girls was common during the nineteenth century but was on the decline. By the 1920s the practice was almost obsolete. Implicit in the state's decision not to apprentice white girls was the acknowledgement that 'their sexuality could not be controlled'. ${ }^{31}$ Yet, it was during this period that the Board began to ramp up the removal of Aboriginal girls into indentured situations. Arguably, the intention was not to 'protect them' from 'present surroundings' but to place them in an environment where they would more likely find white husbands or partners.

27 Ellinghaus, 'Absorbing the "Aboriginal Problem"',183-207.

28 Ellinghaus, 'Absorbing the "Aboriginal Problem"', 195.

29 Haskins, 'A Better Chance?', 35.

30 Haskins, 'A Better Chance?', 53.

31 Haskins, 'A Better Chance?', 37. 


\section{Identification of available girls}

By 1916 the Board had created 19 Aboriginal stations across the state. ${ }^{32}$ Each was staffed by a manager/teacher and his wife who looked after the needs of the women and girls. The managers of stations were also required to identify children for removal and inform the Board. Also, under the Act local officers in charge of police had responsibility for the unmanaged reserves and therefore undertook the task of identifying Aboriginal children for removal. ${ }^{33}$ Towards the end of 1914 the Board had expressed frustration that some station managers were tardy in reporting children for removal. A Board circular to all managers began with: 'It is feared that some of the Managers do not understand what is required in connection with [Circular No. 18] regarding youths and girls'. The Board reminded managers to comply. ${ }^{34}$ Perhaps some managers were reluctant to identify individuals for removal. Also, in April 1916 a circular went out to all superintendents of police (stationed at Sydney, Armidale, Goulburn, Depot (sic), Bathurst, West Maitland, Tamworth, Deniliquin, Bourke, Albury) requesting that they provide the Board with particulars of all orphaned or neglected children under the age of 18 'on the various reserves in his district'. It also advised the superintendents to provide:

particulars of children who were not [my emphasis] neglected, but who were living under circumstances which, in the opinion of the Police, are likely to endanger their future moral or physical welfare, should be shown separately at the end of the Return, giving the fullest details ... In every case a definite recommendation should be made as to whether the child should be removed from its present surroundings. ${ }^{35}$

Other institutions also initiated removals. A Board minute entry reads: 'indenture between Aboriginal Girl " $Y$ " and the Australian Aborigines Mission'; Board response: 'Approved' ${ }^{36}$ However, on this occasion, Board

32 Protection of Aborigines: Report of the Board (the APB Report: hereafter APBR) 1916, Appendix A. Accessed via NSW Legislative Assembly: Aborigines Report of Board for the Aborigines 1915-1922, Q572.991 N, State Library of New South Wales (hereafter SLNSW).

33 Under the Aborigines Protection Act 1909 (NSW), Regulation 28c gave the police authority on the unmanaged reserves.

34 APB Circular No. 1, 10 November 1914, Copies of letters sent 1914-27, 4/7128, Reel 1853, State Records of New South Wales (hereafter SRNSW).

35 APB Circular No. 67 to Superintendents, 1 April 1916, Copies of letters sent 1914-27, 4/7128, Reel 1853, (SRNSW).

36 APBM, 2 August 1916, Item 15. 
secretary Robert Beardsmore wrote to Mrs L.W. Long of the Aborigines Inland Mission, stating the Board's mild displeasure at not being 'kept in the loop'. His letter also reveals how 'ad hoc' the removal process could be:

A case has recently come under my notice in which $\mathrm{Mr}$ Smith of the Singleton Home has arranged to send out a girl to service. While the Board are [sic] always willing to accept your recommendation for the placing of girls from Singleton Home in suitable situations, might I suggest the desirableness of instructing Mr Smith to, in future, communicate with this office when he has a girl ready to send out, and stating where he suggests she should go. ${ }^{37}$

Another example of a removal likely initiated by an institution is told by Dharawal men Les Bursill and his cousin Bryan Smith. It relates to the placement of one of their relatives, an eight-year-old Aboriginal girl at a convent in Tempe. Les was told it occurred just before the First World War when the girl was taken by the police in a horse drawn wagon' and removed to the convent; neither men could say if the girl's mother knew of the impending removal. At age eight, she was far too young to be apprenticed - usually the girls went straight to Cootamundra Training Home until they were 14. Most likely, a request had come from the convent to the Board for an Aboriginal domestic servant. The girl worked in the convent for the next six to seven years. Her job was to 'push down the clothes into boiling vats of soapy water - she was a laundry maid, ironer, and starcher'. At the end of it all 'she was given a florin'. Bryan Smith remarked that she was 'a slave in that place'. At the age of around 18, and without any notice, she was returned, unannounced to her mother by the police. ${ }^{38}$

37 Letter from Robert Beardsmore to L.W. Long, 15 March 1914, Aborigines Inland Mission, Records, 1904-1988, MLMSS 7895, Folder 1905-1923, Correspondence primarily from the NSW Office of the Board for the Protection of Aborigines, Mitchell Library (hereafter ML). The Singleton Home, run by the Aborigines Inland Mission, was for Aboriginal boys and girls from birth until 14 years of age. The property was bought by the Board around 1918. See also: www.findandconnect. gov.au/guide/nsw/NE01616.

38 Les Bursill and Bryan Smith, interview by the author, 12 July 2017, at Worrigee (near Nowra). There is no record of this girl in the Board minutes or the Ward Registers. The vast majority of girls went into domestic service in residential homes but the placement in a convent was unusual. As seen in Chapter 3, many requests for domestic servants came to the Board. Both men said that she was taken around the age of eight years old; however, if Olive was at the convent for seven years, she would only be 15 and not 18 when she returned home. She may well have had another placement after the nunnery of which they were unaware. 


\section{Aboriginal pushback}

The Board regularly employed strategies to encourage compliance. Homefinder Miss Lowe was often tasked with explaining to Aboriginal mothers the benefits of 'giving up' their girls. ${ }^{39}$ If persuasion failed then the Board withheld 'aid' to the girls and directed the family 'to secure suitable situations locally to the satisfaction of police, within a period of [a] month'. ${ }^{40}$ If they declined to do so then the Board made the 'suitable' arrangement. In some cases when the Board met with stiff resistance it seemed reluctant to use its own powers. In 1919, the mother of a 14-yearold 'half-caste' girl at Brungle Station refused to allow her daughter to be removed to Cootamundra Training Home for Girls. The Board minutes record that proceedings to "be instituted under the Neglected Children and Juvenile Offenders Act in the event of the mother persisting in her refusal to allow the child to be transferred to Cootamundra Home'. ${ }^{41}$ This course of action was not necessary. The Board chose not to enforce its own powers under the 1915 amendment to the Aborigines Protection Act 1909 (NSW). Perhaps the Board believed that the removal of a child from Brungle by the police would create a negative public reaction. To hide under the state's Neglected Children and Juvenile Offenders Act 1905 may have been a more palatable approach.

A similar situation developed at Bulgandramine Reserve (just north of Parkes). Inspector Donaldson had recommended the removal of two sisters but the parents refused to let them go. The Board instructed the police to interview the girl's parents 'with a view to ... persuade them to consent'; in the event of their failing to acquiesce, it advised that the parents should be 'warned the children will be brought before the court'. ${ }^{42}$ There is no further mention of this incident, but clearly the parents were reluctant to give their children up and the Board tended to avoid any public incidents. In later life, Board Secretary Pettitt reflected in an interview that there were 'some instances where there was trouble getting the girls away very naturally' and he admitted to the use of force:

\footnotetext{
Cole, 'The Glorified Flower', 70. $A P B M, 14$ September 1916, Item 15. $A P B M, 15$ October 1919, Item 20.

$A P B M, 12$ November 1919, Item 9.
} 
I mean to say there was a lot of hostility and some of these circumstances where I suppose, they were unavoidable but in some cases, I believe that girls were taken away when there was an uproar on the station because of their forcible transfer. ${ }^{43}$

After three girls 'were seized and sent to Cootamundra' from Cumeroogunga Station on the Murray River in 1919, there was a fear of further removals. Sixteen Aboriginal families fled to the safety of Victoria and would not return until they were guaranteed a fair court hearing. ${ }^{44}$

The APB, sensitive to negative publicity, held the view that it would 'adhere to its current practice of bringing children to the courts ... rather than summarily removing them under the provisions of the Aborigines Protection Act ${ }^{\prime}{ }^{45}$ Due to parental resistance and the subsequent movement of Aboriginal families away from the stations, summary removals had to be tempered. In 1922, to prevent families from leaving the stations, the $\mathrm{APB}$ sent out a circular to all managers and teachers to 'dissuade them [Aboriginal families] from leaving the stations to the reserves where there is no supervision'. ${ }^{46}$

\section{The record of removals}

Significant difficulties face researchers of records concerning Aboriginal child removals in New South Wales from 1883 to 1940. The Ward Registers 1916-28 are the only surviving archive that records the names and relevant details regarding the placements of young Aboriginal girls and boys who were removed by the Board. ${ }^{47}$

The archive contains the records of 800 children removed between 1916 and 28. It is the most important archive of the period. Even so, the archive remains challenging due to its fragmentary, unclear and ambiguous nature. Some names and places are difficult to decipher. As a result,

43 A.C. Pettitt, interview by J.J. Fletcher, 1977, Audio-tape J01-018426, Australian Institute of Aboriginal and Torres Strait Islander Studies (hereafter AIATSIS) Library, Canberra.

44 Daily Herald (Adelaide), 28 April 1919, 2; and the Albury Banner and Wodonga Express, 2 May 1919,35 .

$45 A P B M, 13$ September 1922, Item 4.

46 APBM, 13 September 1922, Item 4.

47 Aborigines Welfare Board - Ward Registers, 18 January 1916 - 2 June 1926; 28 May 1924-27 and December 1928, NRS 26, Original location 4/8553 and 4/8554; Reel 2793 (SRNSW) (hereafter referred to as Ward Registers, 1916-28). 
researchers can differ in their interpretation of the number of children recorded therein. For instance, I found six double entries while Naomi Parry found seven duplicates. ${ }^{48}$ Generally though, historians who have looked at this archive have agreed that 800 children (approximately 570 girls and 230 boys) were removed between 1916 and $1928 .{ }^{49}$ There is a second archive, called the Index to Ward Registers, 1916 - c.1938, but this Index only lists the names of the children who were made wards, with no other details regarding their removal. ${ }^{50}$ It does include the names of the 800 children detailed in the Ward Registers. The Index also records the names of 654 additional children removed. In a third archive there are the names of a further 128 children are listed but with no details. ${ }^{51}$ Together, these registers document the removal of 1,582 individual Aboriginal children in New South Wales.

Each entry in the Ward Registers is filled out on a template - called a 'Register form' - with the following headings: entry number, date at beginning of entry, name of child, age, birthday, place of birth, religion, reason for the Board assuming control, father's name and occupation and address, mother's name and address, other relatives, how many brothers and sisters with names and ages, previous placements in other situations, where placed and for how long, further particulars (where living during childhood and in whose care), to which institution sent and when, the certificate of admission and the relevant 'disposal'. The 'disposal' section of the files records where the children were initially placed and their subsequent placements. The name of the person/household where the child was sent, the location and the date are consistently recorded. There are, however, many gaps in the information under each heading; for example, no birthdate or place of birth, no details for the mother or siblings, and so on. In some cases, information is indecipherable. These gaps can lead to potential misreading of the evidence, or assumptions made, leading to the minor statistical differences drawn by researchers viewing the same file. Table 6.1 below lists a sample of some of the reasons the Board recorded for removal.

48 Ward Registers, 1916-28, Nos 166 and 130; 538 and 681; 676 and 550; 677 and 549; 678 and 548; 604 and 669. Parry, 'Such a Longing', 285.

49 Read, The Stolen Generations, 10; Parry, 'Such a Longing', 285-90; Walden, 'That Was Slavery Days', 196; Haskins, 'A Better Chance?', 43; Windschuttle, The Fabrication of Aboriginal History, 76.

50 Index to Ward Registers, 1916 - c.1938, NRS 27, location 4/8555-56, Reel 1649 (SRNSW).

51 Windschuttle, The Fabrication of Aboriginal History, 76. 
Table 6.1: Reasons recorded by the Board for the removal of children, organised under four categories.

\begin{tabular}{|c|c|c|c|}
\hline Training & Situation & Age & Other \\
\hline $\begin{array}{l}\text { to send to service from } \\
\text { surroundings of camp } \\
\text { life }\end{array}$ & $\begin{array}{l}\text { abandoned by her } \\
\text { mother }\end{array}$ & $\begin{array}{l}\text { attaining school } \\
\text { age }\end{array}$ & aboriginal \\
\hline $\begin{array}{l}\text { to train for domestic } \\
\text { service }\end{array}$ & orphan & to attend school & at own request \\
\hline $\begin{array}{l}\text { to send to service and } \\
\text { give a better chance } \\
\text { in life }\end{array}$ & neglected child & past school age & $\begin{array}{l}\text { transferred } \\
\text { to the State } \\
\text { Children's Relief } \\
\text { Department }\end{array}$ \\
\hline to fit for situation & death of mother & $\begin{array}{l}\text { having attained } \\
\text { the age of } 14 \\
\text { years }\end{array}$ & - \\
\hline to train for a situation & $\begin{array}{l}\text { parent's dead; } \\
\text { neglected }\end{array}$ & $\begin{array}{l}\text { too old to stay } \\
\text { longer at reserve } \\
\text { (aged 14) }\end{array}$ & - \\
\hline apprenticed & $\begin{array}{l}\text { parents unable to } \\
\text { support, living destitute }\end{array}$ & - & - \\
\hline to be apprenticed & $\begin{array}{l}\text { living on mission camp } \\
\text { and not under proper } \\
\text { care of parents }\end{array}$ & - & - \\
\hline to have him trained & $\begin{array}{l}\text { likely to lapse into } \\
\text { career of vice }\end{array}$ & - & - \\
\hline $\begin{array}{l}\text { to have advantage of } \\
\text { proper training and } \\
\text { protected against the } \\
\text { risk of going to the bad }\end{array}$ & $\begin{array}{l}\text { to better her } \\
\text { conditions \& take } \\
\text { from surroundings of } \\
\text { Aboriginal Station }\end{array}$ & - & - \\
\hline $\begin{array}{l}\text { to send to service as } \\
\text { not to lead idle life on } \\
\text { reserve }\end{array}$ & $\begin{array}{l}\text { to improve conditions } \\
\text { of living; living under } \\
\text { conditions that would } \\
\text { lead her to a career of } \\
\text { vice and crime }\end{array}$ & - & - \\
\hline for domestic service & - & - & - \\
\hline
\end{tabular}

Source: Ward Registers, 1916-28.

It is interesting to note how Keith Windschuttle has interpreted the Ward Registers. To support his argument that the Board acted appropriately, he concluded that a total of 526 , or 65.75 per cent of the 800 children, were removed for what he asserts were reasonable motives. From the record he determined that the Board removed: 173 on the grounds that they went 'into apprenticeship or employment'; 113 who were deemed 
'neglected'; 73 for being 'orphaned'; 62 to 'improve the child's condition of living'; 52 to 'go into education or training; and 53 at the request of the State Children's Relief Board..$^{52}$ But what Windschuttle ignores is that the Board had absolute discretion to determine whatever reason it chose to remove the children. There was no independent scrutiny or oversight of the Board in this matter, thus making a mockery of Windschuttle's breakdown of reasonable motives.

The reason could have been provided by either of the two inspectors, a local policeman, the manager of an Aboriginal station or an officer of the APB acting on information from the stations and reserves. As can be seen in Table 6.1, many of the reasons are insufficient to justify the removal of a child or adolescent from their family or community. Herb Simms was born at La Perouse in 1926 and was sent to Bomaderry Aboriginal Children's Home at three years of age. After six years he was transferred to Kinchela Boys Home. Years later, Herb recalled as a young lad how the police and station managers had extraordinary powers:

we were mindful ... that the police themselves could go in and drag Aboriginal kids out and take them all without question from their homes. There would be the manager of the Aboriginal settlement who could do the same thing. ${ }^{53}$

Naomi Parry argues that the Board threatened parents with neglect proceedings if they did not give up their children: this was blatant intimidation. But also points out that the rate of parental surrenders was very low at 5 per cent, like that among white families. Parry found only two cases of 'surrender' and both were short-term placements. One mother applied to the Board for respite from her 18-year-old daughter for a few months; and a Moonacullah (north-west of Deniliquin) woman who had been 'deserted by her husband' reclaimed her four children after 'securing housing and employment'. ${ }^{54}$ This would suggest that almost all removals were resisted.

52 Windschuttle, The Fabrication of Aboriginal History, 93-94.

53 Herb Simms, interview by Fred Maynard, 7 April 2001, La Perouse, Bib ID: 950973, ORAL TRC 5000/263, National Library of Australia (hereafter NLA).

54 Parry, 'Such a Longing', 287. 


\section{The removal of Aboriginal children into apprenticeships}

The following analyses calculate the number of children removed from numerous communities and sent into apprenticeships across the state. Also, by tracing the movements of the apprentices from Dharawal Country, I endeavour not only to personalise the removals but also to demonstrate the vast distances that many travelled, and the number of placements they endured.

The statistics are solely derived from the Ward Registers 1916-28, and it must be stressed that they are far from complete for this period. Therefore, there are limitations to the analyses that follow. First, the Index to the Ward Registers (listing 654 Aboriginal children removed) is not mentioned below because there are no details about the children removed. Second, as Board reporting was so tardy, particularly after 1916, no researcher could be confident that all Board reporting was accurate, let alone comprehensive. Third, the Board was totally unaccountable to any person or authority in compiling its statistics. Fourth, as already mentioned, there are differences of accounting among historians who have viewed this archive. Furthermore, Aboriginal families across New South Wales will be able to attest to children being removed from locations that do not appear below.

\section{Aboriginal girls removed}

In the absence of any consistent historical regional reporting by the Board, I have used the current New South Wales Aboriginal Land Council (ALC) boundaries to represent the regions throughout New South Wales (Figure 6.1). ${ }^{55}$

The ALC has nine regions: North Western, Wiradjuri, Northern, Mid-North Coast, North Coast, Central, Sydney/Newcastle, Western, and South Coast.

55 The Board reports provided census figures based on individual locations across the state. From 1883 until 1911 (28 years) it listed the census locations, usually in alphabetical order, as detailed by the local police officer in the district. From 1911 until 1915 (5 years) the Board then divided its census report into nine regions: metropolitan, northern, southern, eastern, western, north-eastern, northwestern, south-western, and Murray. For the next 24 years the Board failed to report any breakdown in its census figures. Without any consistency of reporting from the Board, I have therefore chosen more recent Aboriginal Land Council boundaries to reflect the spread of removals. 


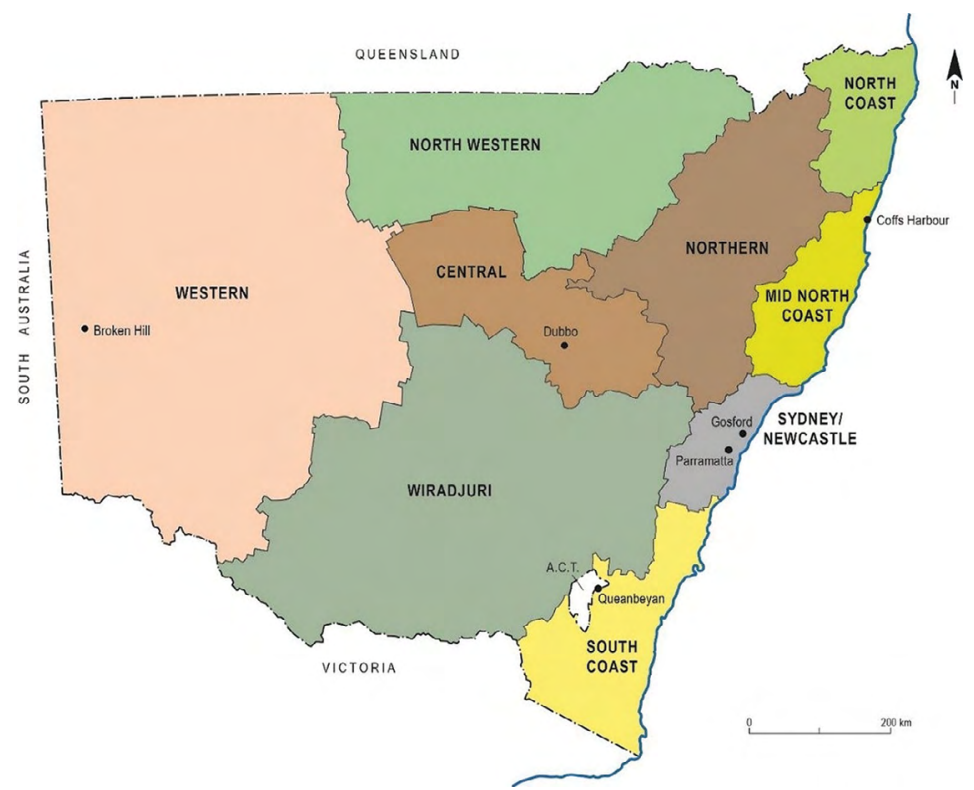

Figure 6.1: Map of New South Wales Aboriginal Land Council boundaries.

Source: alc.org.au. Cartographer: Peter Johnson, Cordeaux Heights, NSW.

The archive records the placement of 501 girls into apprenticeships by the Board. This number is short of the accepted figure of 570 only because some girls were placed by the State Children's Relief Board, some into George Ardill's Homes and others into hospitals/asylums. The figures below only represent those girls who were apprenticed.

The greatest number of girls (438) removed and subsequently placed into domestic service were from regional locations across New South Wales, while 11 more were taken from Sydney and Newcastle (Figure 6.2). Seven more girls were removed, but the locations from where they were taken could not be determined. An additional 41 girls were placed in domestic situations after being removed from New South Wales institutions. This latter group is represented separately because we do not know from which region the girls originally came. There were also four girls from interstate placed into apprenticeships in New South Wales (see Appendices). ${ }^{56}$

56 Inara Walden records that 570 girls were removed (Walden, 'That Was Slavery Days', 96). Victoria Haskins records a total of 570 girls removed and identifies 514 wards who were apprenticed. (Haskins, 'A Better Chance?', 43); Keith Windschuttle concludes that it is possible to identify the sex of 781 files, of which 557 were female and 224 were male (Windschuttle, The Fabrication of Aboriginal History, 76). The discrepancies reflect the difficulty in reading the files; sometimes the records are illegible, and some entries are open to interpretation. 


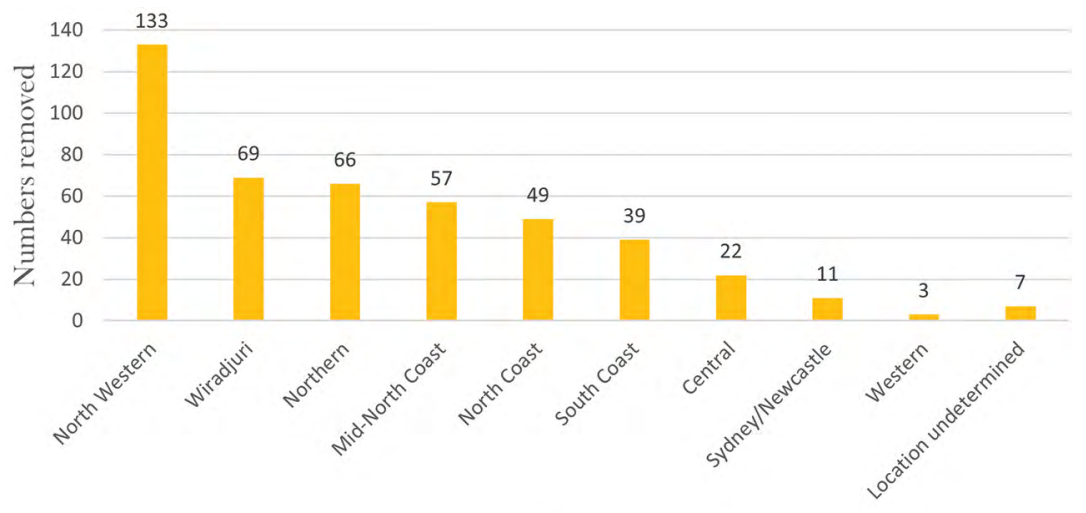

Regions

Figure 6.2: Numbers and regions from where Aboriginal girls were removed and subsequently placed in apprenticeships (1916-28). Total: 456.

Regions are based on the current New South Wales Aboriginal Land Council boundaries. Source: Author's summary of Ward Registers, 1916-28.

Figure 6.2 demonstrates two interesting findings. First, the removal of Aboriginal girls among New South Wales regions was uneven. Second, one region, the North Western, bore the brunt of the removals with 133 out of 449 girls, or 29.6 per cent, coming from this area of the state. Also, data on removals within each region, shown with further graphs in the Appendices, demonstrates that some Aboriginal stations and reserves bore a disproportionate burden of removals: the highest numbers of girls removed from each region were drawn from Aboriginal stations or reserves, but it should be noted that girls were also removed from towns that had no appended stations or reserves, including Barmah, Blayney, Forbes, Tamworth, Armidale, Broke, Stanthorpe, Gloucester, Nambucca Heads, Tweed Heads, Kiama, Port Kembla, Mudgee, Bowral and Cabramatta. Aboriginal families living independently of the Board were not immune to the Aborigines Protection Act 1909. Section 11(1) stated: 'The board may ... by indenture bind or cause to [be] bound the child of any [my emphasis] aborigine ... to be apprenticed to any master'. ${ }^{57}$

Moreover, of those 133 girls, who were removed from the North Western region, 78 or 58.6 per cent came from just three locations: Brewarrina, Angledool and Pilliga (Figure 6.3).

57 Aborigines Protection Act 1909 (NSW). 


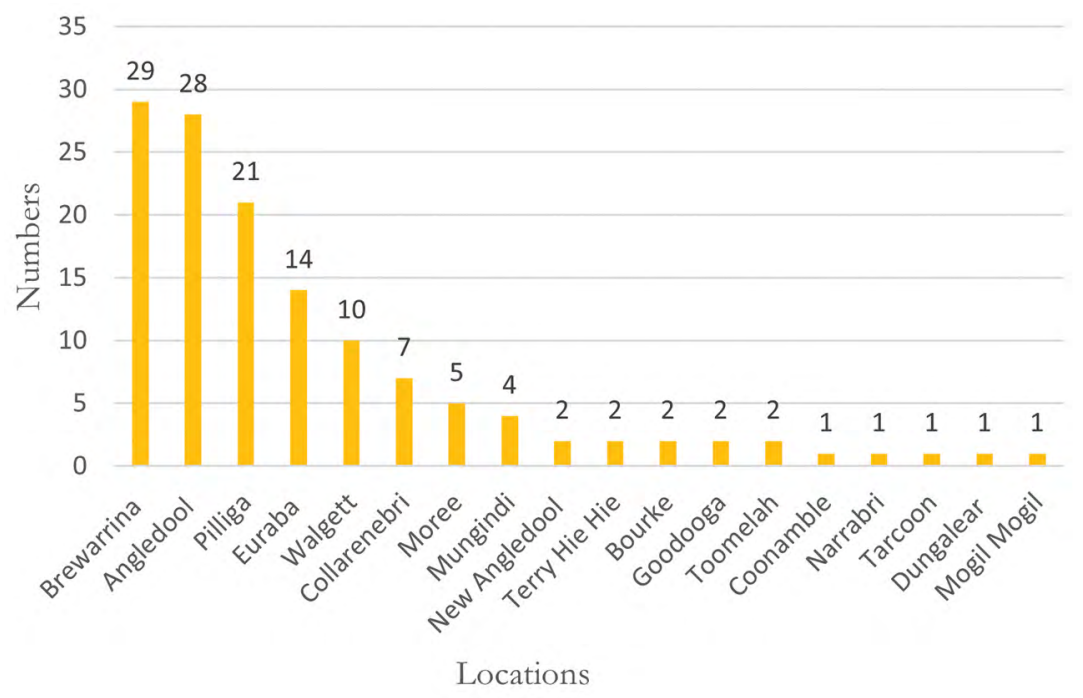

Figure 6.3: Numbers of Aboriginal girls removed from locations within the North Western region (1916-28). Total: 133.

Source: Author's summary of Ward Registers, 1916-28.

These three locations also play a similar role, but even more predominantly, in the removal of Aboriginal boys.

\section{Aboriginal boys removed}

The removal of Aboriginal boys was similarly most concentrated in the North Western region (Figure 6.4). A total of 152 Aboriginal boys were removed from identifiable locations and placed in apprenticeships; seven locations could not be identified. Fifteen boys were removed directly from Aboriginal Boys' Homes, making a total of 174 boys removed and placed in apprenticeships between 1916 and 1928. As with the Aboriginal girls who were removed, fewer boys were taken from institutions. Of the 174 boys removed, more than 91 per cent were from stations and reserves. A breakdown of each region can be found in the Appendices.

As with the girls within the North Western region, Brewarrina, Angledool and Pilliga are over-represented in the removal data. Of the boys removed in this region 51 of 84, or 60.7 per cent, came from these three locations (Figure 6.5). 


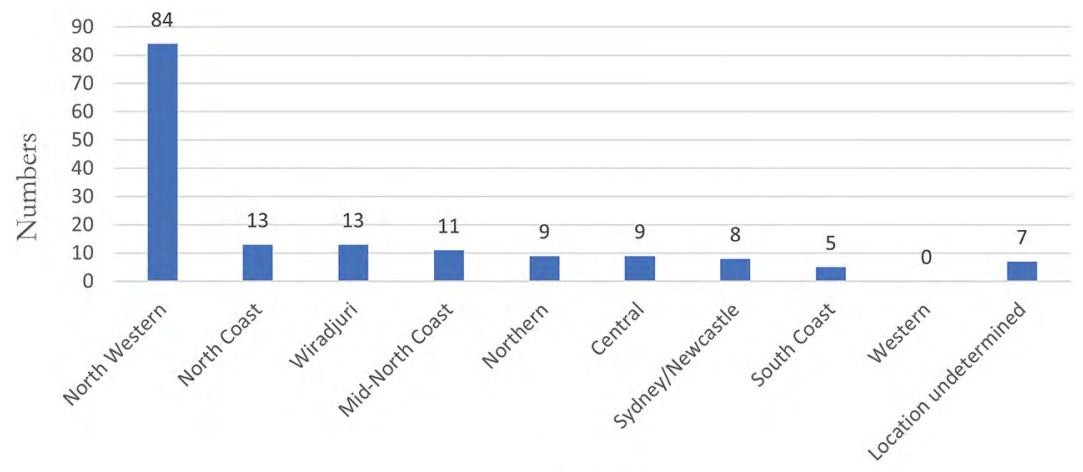

Regions

Figure 6.4: Numbers and regions from where Aboriginal boys were removed and subsequently placed into apprenticeships (1916-28). Total: 159.

Regions are based on the current New South Wales Aboriginal Land Council boundaries. Source: Author's summary of Ward Registers, 1916-28.

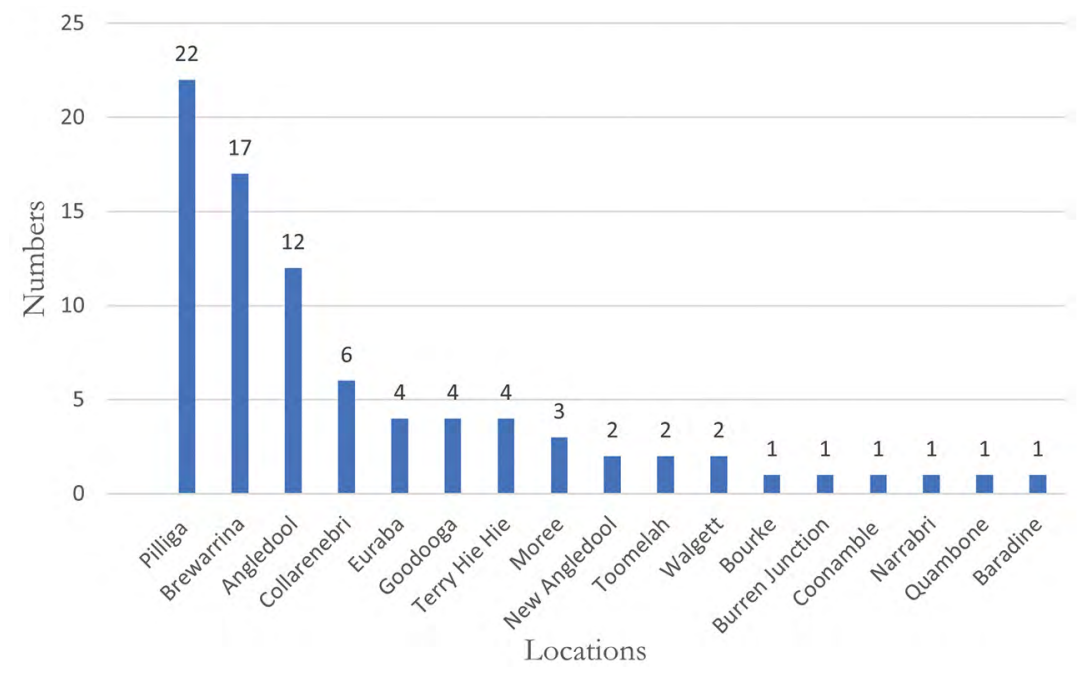

Figure 6.5: Numbers of Aboriginal boys removed from locations within the North Western region (1916-28). Total: 84.

Source: Author's summary of Ward Registers, 1916-28.

In summary, this limited record suggests that 675 Aboriginal children (501 girls and 174 boys) were placed into apprenticeships between 1916 and 1928. The obvious question is why did most of child removals come from the North Western region? Of the 675 children/adolescents placed into apprenticeships, 217 (133 girls and 84 boys), or 32 per cent, came 
from this region. Moreover, in the breakdown of removals within the North Western region, three main centres - Brewarrina, Angledool and Pilliga - stand out as locations from where 129 children $(51$ boys and 78 girls) were removed. This figure represents 19 per cent of the removals from across New South Wales. No other location point had higher raw numbers of removals than these three.

Some observations can be made about these three locations. First, Angledool and Pilliga were not major Aboriginal population centres, but Brewarrina was. Figure 6.6 represents population levels of just 17 location points, not necessarily a station or reserve, over the five-year period from 1911 to 1915, with an Aboriginal population close to or above $100 .^{58}$ Brewarrina, Angledool and Pilliga (far right) have been included to show a direct comparison.

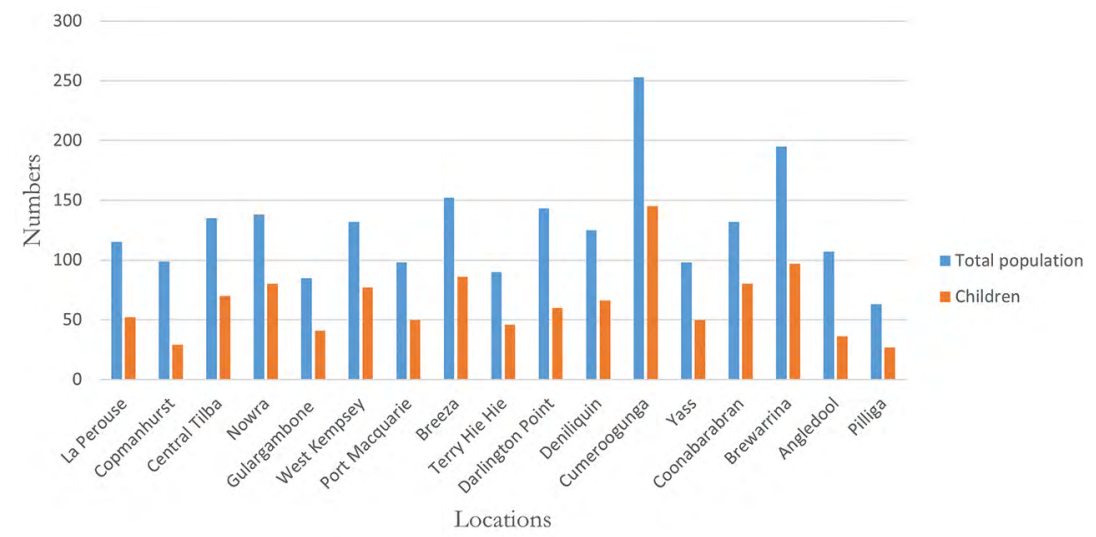

Figure 6.6: Mean total Aboriginal populations at major Aboriginal concentration centres from 1911 to 1915. Numbers of children are included in the total population columns and are also represented separately.

Source: Author's summary of APBR, 1911-15.

Brewarrina was a significant population centre; in fact, it was the second largest in the state after Cumeroogunga. Angledool was close to the mean population of other main centres while Pilliga was at the lower end of numbers. Cumeroogunga clearly had the largest population of both adults and children in 1915, so you would expect significant removals

58 As outlined in Chapter 5, the APB reduced its reporting after 1916. After 1915 and for the next 24 years, the Board failed to produce any breakdown census figures for the various regions and stations as it had done prior to 1916 . 
from here. Yet, only nine girls were removed from Cumeroogunga under the period under discussion (see Appendices). There were other locations with lower populations and from where more girls were removed: Burra Bee Dee (near Coonabarabran), Warangesda (Darling Point) and Roseby Park (near Nowra) all had populations approximately half that at Cumeroogunga, yet the number of girls removed from these locations were higher (18, 16 and 10, respectively) (see Appendices). Therefore, the overall population of centres or stations was not the predominant factor in determining removals.

Second, the children targeted for apprenticeship were generally not 'fullbloods' but 'half-castes', or those children with 'less than an admixture of Aboriginal blood'. ${ }^{59}$ So you would expect to see locations with a higher concentration of 'half-caste' children to be targeted for removal. However, an examination of the breakdown of 'full-blood' and 'half-caste' children at the locations from where more than 10 girls were removed does not support this (Figure 6.7).

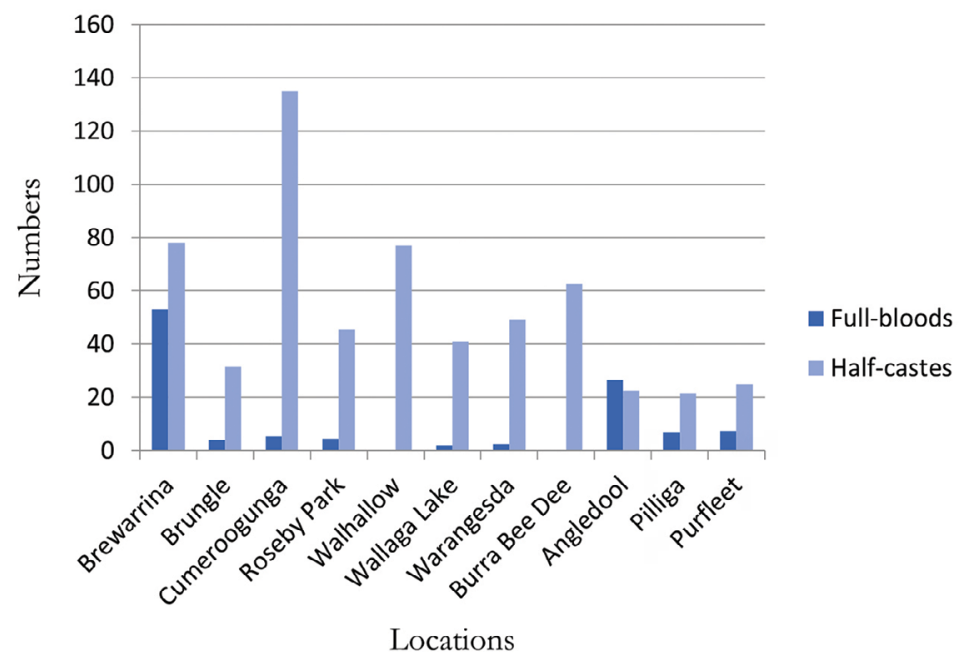

Figure 6.7: Numbers of 'full-blood' and 'half-caste' children at location points between 1911 and 1912 from where 10 or more girls were subsequently removed. ${ }^{60}$

Source: Author's summary of APBR, 1911-15.

59 There are numerous references to the Board targeting children classified as 'half-caste' or 'quadroons' and 'octoroons'. See Chapter 4.

60 The Board statistics are only consistent, for the breakdown of children on this basis, for these two years. 
Both Brewarrina and Angledool had the highest percentage of children who were classified as 'full-bloods'. Arguably, then, you would not expect to see large numbers removed from Brewarrina or Angledool. Brewarrina did have a large 'half-caste' population, but in comparison to other locations, Angledool and Pilliga did not, and should not have been overly targeted. Heather Goodall argues that the 'full-blood' children and adolescents were targeted just as much as those with a 'lesser admixture of Aboriginal blood', so this may not be a valid distinction. The Board did allow for the removal of 'full-blood' children but stipulated that they should not be sent too far away from their communities. ${ }^{61}$ The main thrust of Board policy was the removal of the 'half-caste', 'quadroon' and 'octoroon' population. However, it may not have been implemented on the ground and poor reporting on the status of each child in this regard removes the opportunity to check this. ${ }^{62}$

From 1916, only three Board reports indicated where the inspectors travelled during those years. A situation may have arisen whereby the inspectors concentrated on the North Western region for some reason in the other years. ${ }^{63} \mathrm{~A}$ further examination of the archive to ascertain any trends of spikes or troughs in removals for each year from 1913 to 1929 did not provide any clear evidence to that end; the only clear trend was a reduction in removal activity in 1928, which coincides with Inspector Donaldson's retirement through ill health. ${ }^{64}$ One can only speculate as to what caused this intense interest in this area to remove Aboriginal children. Perhaps the North Western region had a cluster of overzealous managers or local police. One thing, though, is clear. The newly reconstituted Board from 1916, primarily run by the trio of Secretary Pettitt, Inspector Donaldson and Miss Lowe, had carriage of these removals. I would suggest that the Board's actions were arbitrary, but also influenced by compliant managers and local police. In addition, the degree of Aboriginal resistance may also have influenced Board removal activity. Significant press coverage of the

$61 A P B M, 6$ April 1916, Item 1.

62 The Ward Registers, 1916-28, sometimes record whether a child was a 'full-blood' or 'half-caste', but these data are too infrequent.

63 APBR 1916, 2; 1918, 1; 1921, 1. Accessed via NSW Legislative Assembly: Aborigines Report of Board for the Aborigines 1915-1922, Q572.991 N. (SLNSW). No other reports specifically listed their visitations. In a recent email conversation, Heather Goodall suggests that the north-west was targeted after early locations like Cumeroogunga. She also points out that for inland locations like Brewarrina and Pilliga it was difficult to 'escape' the Board, unlike Cumeroogunga or Toomelah on the Victorian and Queensland borders respectively. Also, she notes that in the north-west there was significant opposition from Aboriginal families to the removal of their children. Email correspondence, 3-5 July 2017.

64 Ward Registers, 1916-28. 
16 Aboriginal families fleeing across the Murray River from Cumeroogunga to avoid possible child removals appears to have influenced the Board to stay clear, arguably to avoid public scrutiny ${ }^{65}$ Heather Goodall notes that age, sex 'and proximity to the Board's inspectorial routes of travel' were the only reliable predictors of removal. ${ }^{66}$ Further intensive investigation is required to provide a satisfactory explanation to this interesting finding of disproportionate removals from Brewarrina, Angledool and Pilliga.

\section{Placement of Aboriginal girls and boys into apprenticeships across New South Wales}

\section{Girls}

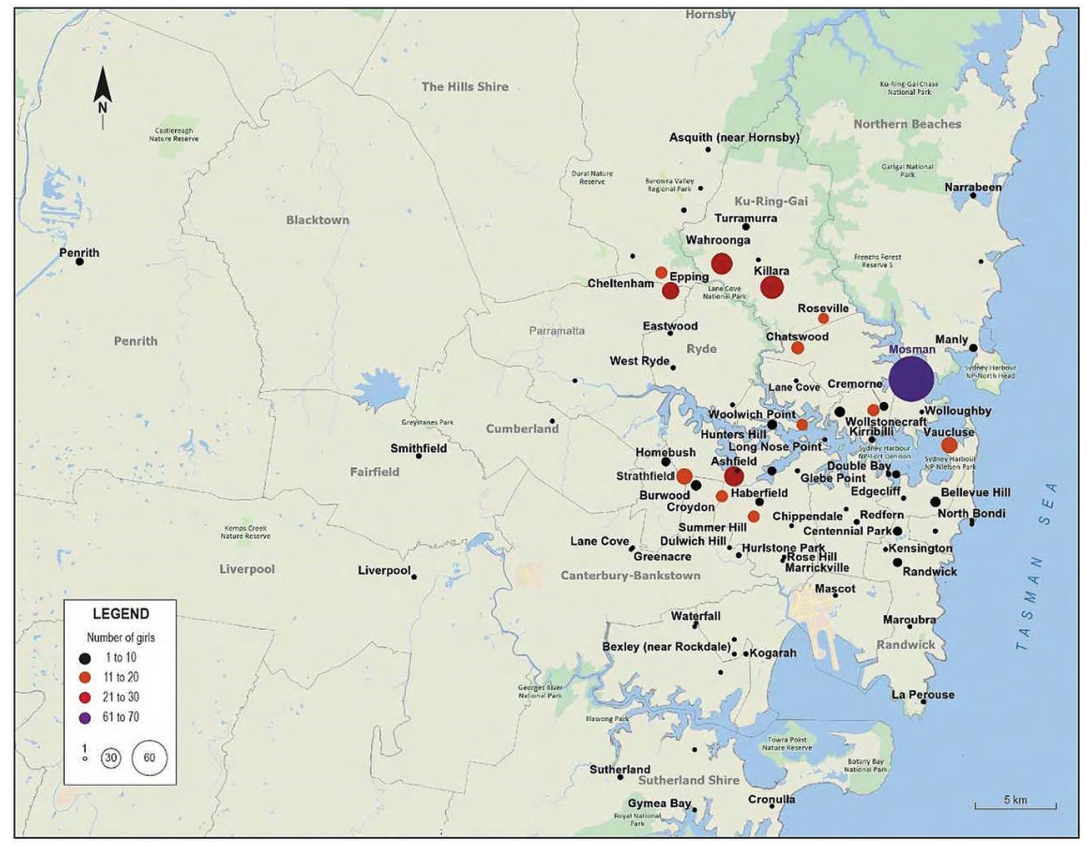

Figure 6.8: Location points in Sydney for the placement of Aboriginal girls who had been removed from their communities.

Source: Ward Registers, 1916-28. Cartographer: Peter Johnson, Cordeaux Heights, NSW.

65 This incident was widely canvassed in the press. See Davis, Australian Settler Colonialism, 36.

66 Goodall, 'Assimilation Begins in the Home', 82. 
Overall, there was a total of 1,184 placements of Aboriginal girls into homes across the state of New South Wales. There were six more placements with details that could not be clearly determined making a total of 1,190. Just under half of the 1,184 placements, 535, were in suburban Sydney. With 501 girls involved overall, clearly, many had several placements.

In the Sydney region, Mosman had 64 placements and was the location that received more Aboriginal female domestic workers than anywhere else (Figure 6.8). Research revealed that there were 33 separate residents in Mosman who took in Aboriginal domestic servants and many of these residents took multiple placements of girls. One Mosman resident used five different girls. ${ }^{67}$ Homefinder Alice Lowe was tasked with the job of securing homes for these girls; but with such a concentration of Aboriginal girls in the suburb of Mosman, some networking by the Mosman residents with apprentices - to circulate the girls - may well have occurred.

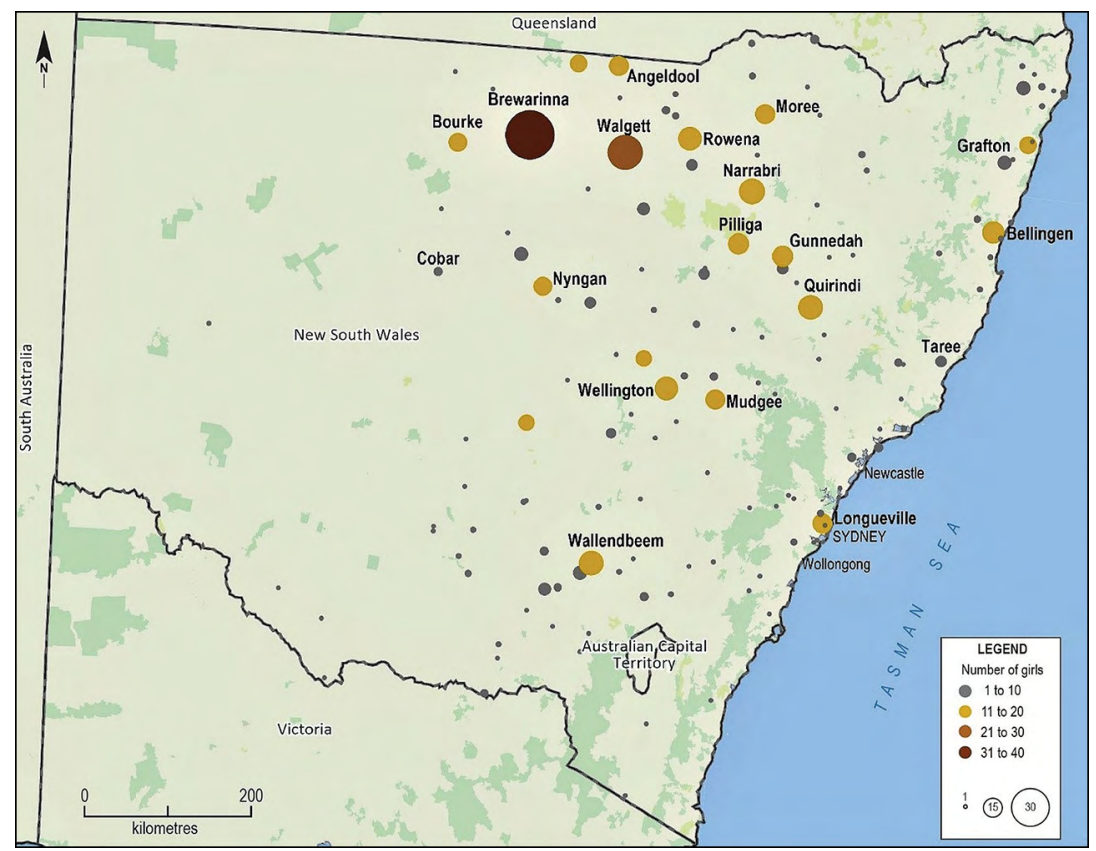

Figure 6.9: Location points in rural New South Wales for the placement Aboriginal girls who had been removed from their communities.

Source: Ward Registers, 1916-28. Cartographer: Peter Johnson, Cordeaux Heights, NSW.

67 Ward Registers, 1916-28. 
In rural New South Wales, Brewarrina was the highest recipient of female domestic workers with 39 placements. Another finding is that many of these locations in both the city and rural areas had only one Aboriginal female domestic worker, a situation that further increased the isolation of these young girls (one small dot on the map represents just one placement).

When examining the top 30 locations for the placement of Aboriginal girls into domestic service across the state (Figure 6.10), this cheap labour was sought in the cities, towns and remote rural areas.

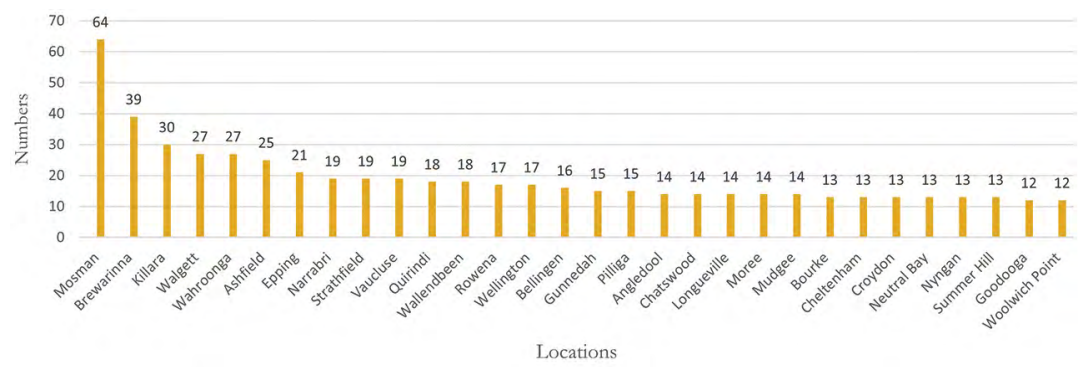

Figure 6.10: The top 30 location points across New South Wales for the placement of Aboriginal girls removed from their communities.

Source: Author's summary of Ward Registers, 1916-28.

\section{Boys}

There were 286 placements of Aboriginal boys (two placement destinations were unidentifiable but are included in the overall total). In contrast to the placement of girls, the boys were almost exclusively placed in rural areas. Thirteen boys (or 4.5 per cent) were placed in suburban Sydney and 273 or 95.5 per cent were placed in country New South Wales. ${ }^{68}$ As with the girls, several placements comprised of only one boy, at a remote location (Figure 6.11).

Brewarrina was by far the most frequent destination for boys who had been removed by the Board, with 34 placements, followed by Gunnedah with 16, and then Pilliga with 12 (Figure 6.12).

68 This figure is close to that of Victoria Haskins, who determined that 98 per cent were in placed in country areas. Haskins, 'A Better Chance?', 43. 


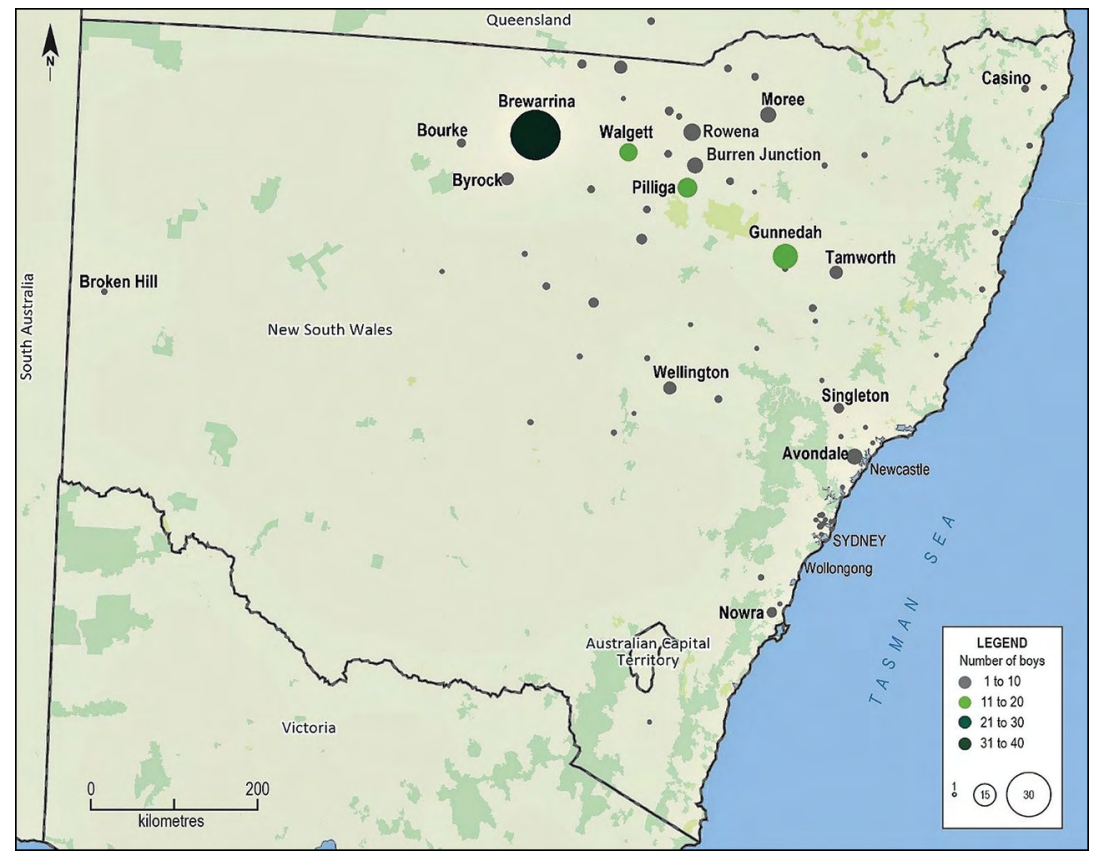

Figure 6.11: Location points across New South Wales for the placement of Aboriginal boys.

Source: Author's summary of Ward Registers, 1916-28.

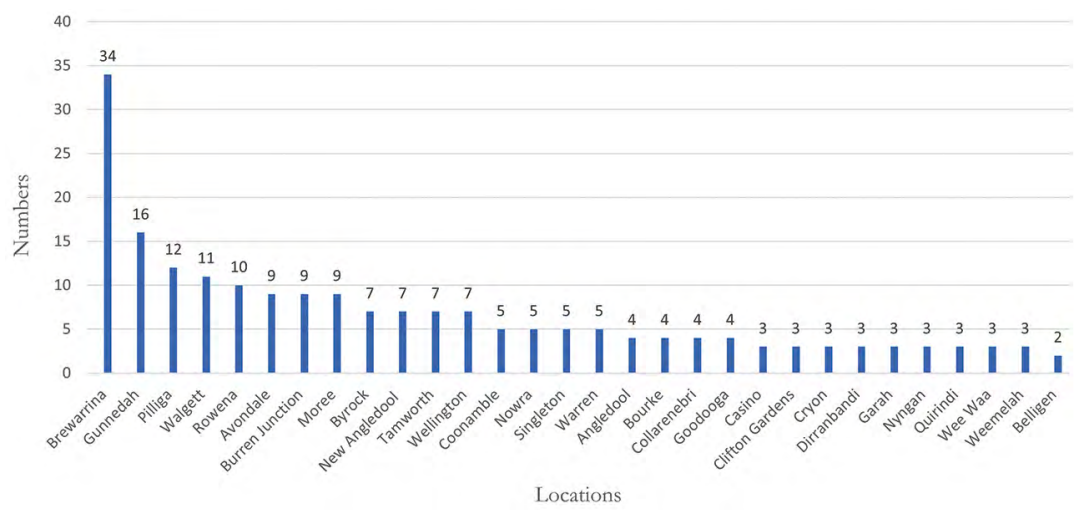

Figure 6.12: The top 30 location points across New South Wales for the placement of Aboriginal boys removed from their communities.

Source: Author's summary of Ward Registers, 1916-28. 
The high number of Brewarrina placements, of both boys and girls, may support the policy of not sending 'full-blood' children too far away from their communities. It is also likely that the fact that some parents, realising their children would be removed, arranged their own placements close to home before the Board made its own decision to place them in more distant locations in Sydney and elsewhere. If parents felt they could not resist the Board due to possible retribution, the practice of 'getting in before the Board' may have occurred on many occasions.

\section{Dharawal Country and multiple placements}

The following data, drawn from Dharawal Country, demonstrates the number of placements some Aboriginal children were forced to endure, and the impact of those apprenticeships on them. It is impossible to determine the number of children within Dharawal Country who were removed to institutions and domestic placements during the period of the first Board (1883-1940) using the extant written records. The only sure way of determining this would be to canvass oral history from Dharawal families. Nevertheless, the Ward Registers reveal that there were 31 children with obvious connections to Dharawal Country who were removed over the 12 years. ${ }^{69}$ They were either born in Dharawal Country or were located within Dharawal Country at the time of their removal. For example, a child may have been born in Kempsey but living permanently with a parent at La Perouse when removed. From a Board perspective, the two main Aboriginal population centres within Dharawal Country were the reserve at La Perouse and the managed Aboriginal station (from 1906) at Roseby Park, opposite Greenwell Point east of Nowra. Most of the girls (19) and all the boys (8) who were removed and placed into service by the Board came from these two centres (Figure 6.13). ${ }^{70}$

69 Ward Registers, 1916-28.

70 There were of course, within Dharawal Country, other Aboriginal population centres. At the year ending 1915, population centres within Dharawal Country were: La Perouse: 124; Nowra:123; Roseby Park: 66; Port Kembla: 60; Mittagong: 31; Burragorang: 21; Kiama: 20. APBR 1916, 6, 10 and 11. 


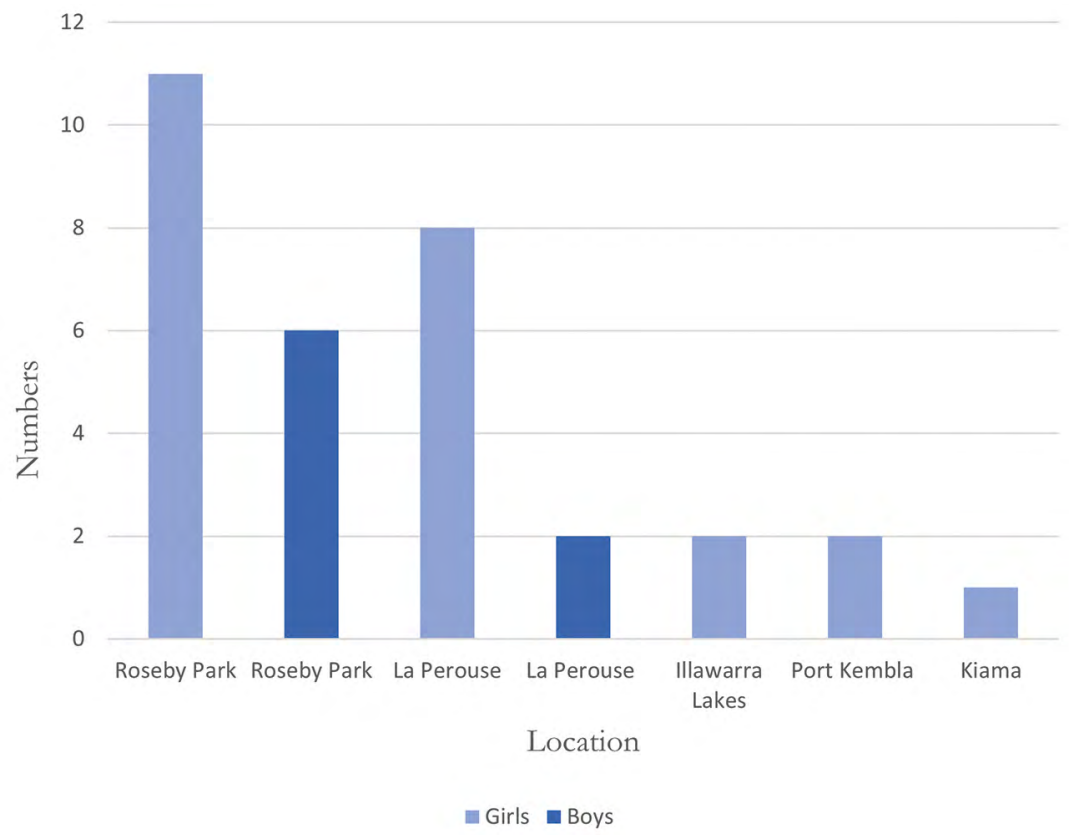

Figure 6.13: Numbers of children removed from Dharawal population centres (1916-28).

Source: Author's summary of Ward Registers, 1916-28.

At Kiama, one girl went into service independently of the Board and has not been included in the figures below as being removed, but this may well have been a result of Board pressure to either do so or face such consequences such as a court referral.

Many of the Dharawal children put into service across New South Wales had multiple placements during their apprenticeships. The 23 girls removed from Roseby Park, La Perouse, Illawarra Lakes and Port Kembla collectively had a total of 94 placements, an average of 4.1 each. ${ }^{71}$ The eight boys from Roseby Park and La Perouse collectively had a total of 22 placements, an average of 2.75 each. Of the 31 apprentices from Dharawal Country, 13 absconded at least once from their placements; this demonstrates that many were clearly distressed in their situations. Only the children themselves and their families know the real pain and anguish associated with these removals. Many children undoubtedly endured long

71 Two of the girls had 'a number of placements' written on their forms, but the placements were unidentified. Therefore, the overall placements of the 23 Dharawal girls would have been even higher. 
periods of suffering through loneliness, separation, rejection, humiliation and abuse. A significant number of girls fell pregnant while in service. Victoria Haskins records that 17 per cent of girls apprenticed to urban situations at some time became pregnant during that time. ${ }^{72}$

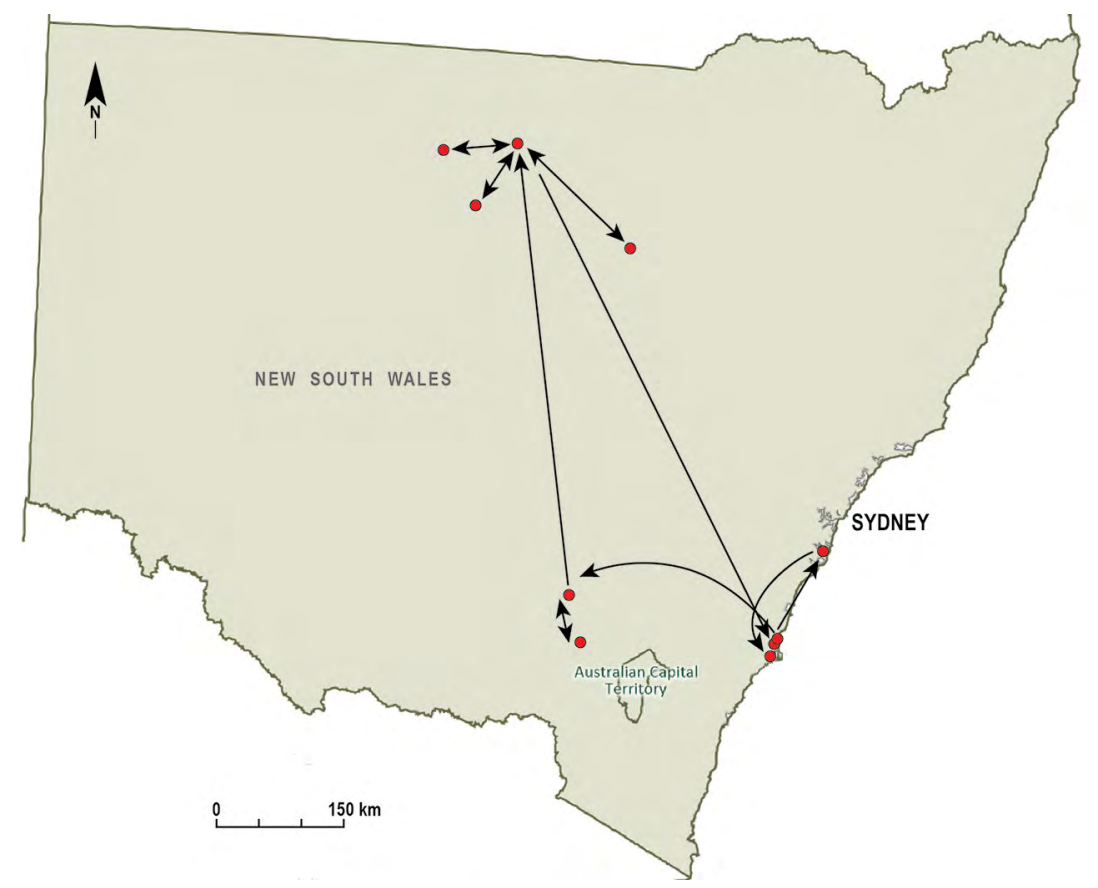

Figure 6.14: Domestic placement history of one Dharawal apprentice.

Source: Ward Registers, 1916-28. Cartographer: Peter Johnson, Cordeaux Heights, NSW.

Figure 6.14 depicts the placement history of one Aboriginal apprentice that took place over a period of 14 years. From the age of eight this child was placed in 10 different locations across the state, with a total of 14 separate placements, and was not free of the Board until their early $20 \mathrm{~s}$.

The words of Aboriginal people as documented in the Bringing Them Home: National Inquiry into the Separation of Aboriginal and Torres Strait Islander Children from Their Families, best reflect the impact. 
From the Bomaderry Home near Nowra:

If we got letters, you'd end up with usually 'the weather's fine', 'we love you' and 'from your loving mother' or whatever. We didn't hear or see what was written in between. And that was one way they kept us away from our families ... We were all rostered to do work and one of the girls was doing Matron's office, and there was all these letters that the girls had written back to their parents and family - the answers were all in the garbage bin. ${ }^{73}$

From a girl placed into service:

The thing that hurts the most is that they didn't care about who they put us with. As long as it looked like they were doing their job, it just didn't matter. They put me with one family and the man of the house used to come down and use me whenever he wanted to ... Being raped over and over and there was no-one I could turn to. ${ }^{74}$

\section{Reflections of Wagga Wagga Elder Isabel Hampton:}

We were coming home from school [North Dubbo] one day when a truck pulled up and asked us, 'Did we want a ride back home?' We got on the back of the truck but it didn't go home. He took us to the police station where they put us in the cells overnight. They had nowhere else to put us at the station. Some missionaries came and talked to us hoping to get us out. They were unable to do that. The next day we were put on a train to Sydney. I think we went to the Aborigines Protection Board Office to sign forms or something. Jack was sent to Kinchela Boys Home and Betty and I were sent by train to Cootamundra. The day Jack left on the train for Kinchela was the last time I ever saw him ... Betty and I spent nine years at Coota. ${ }^{75}$

The impact of the Board's policies as they related to the removal of Aboriginal children and adolescents is incalculable. The fact that some of their voices have now been heard and listened to may well have brought an element of healing. The Board removed children at will, for a range of spurious reasons, relocated them when placements 'broke down', had no apparent regard for the welfare of the children, and left them to the whims of masters and mistresses across the state. Board secretary Arthur 
Pettitt, at the 1937 Canberra conference of Commonwealth and State Aboriginal Authorities, confirmed the total neglect of the Board. In reply to statements 'made about aboriginal girls in domestic service becoming pregnant', Pettitt remarked, 'we throw the responsibility on the employer for the physical and moral well-being of the apprentices'. ${ }^{76}$ Board inspections of the girls in Sydney were 'sporadic and superficial' and in the rural areas they were limited to inquiries by the 'Board, managers or police'. ${ }^{77}$ And, as Victoria Haskins has recorded, if the Board did find out about a pregnancy while in domestic service, the Board invariably blamed the girl, subjected her to a 'stern, even vituperative lecture', moved her on to another posting, and then supplied the client with another girl. ${ }^{78}$ When one considers that hundreds of Aboriginal children were left in situations, far from any independent scrutiny, some of which were clearly dangerous, then the whole apprentice system could only be seen as completely out of control. It is a terrible indictment of successive governments that allowed this small administrative body to act with such cruelty, negligence and impunity.

Not only were Aboriginal girls to be removed, but the Board insisted that after their apprenticeships they should never be allowed to return to their families and communities. Thankfully, the Board was unable to fully implement this pillar of its agenda.

\section{A failed Board policy}

Of the 23 girls from Dharawal Country who were removed it can be determined that nine girls returned to their communities and the records suggest that of those nine, six married into their communities. Seven were married away from their communities, but it is unclear whom they married. It is also unknown whether the five girls who did not return married. Sadly, one girl died in Long Bay goal and one more remained incarcerated there. ${ }^{79}$ At least half the girls, across the state, returned to their place of origin and many married back into their community. ${ }^{80}$

76 Aboriginal Welfare: The Initial Conference of Commonwealth and States Aboriginal Authorities, April 1937, Q353.53499/10 (ML), 16.

77 Haskins, 'A Better Chance?', 48.

78 Haskins, 'A Better Chance?', 51.

79 Ward Registers, 1916-28.

80 Haskins, 'A Better Chance?', 41. 
This was against Board policy. In 1915, as outlined above, the Board was 'quite open' in its determination that the girls were never to return to their communities; they would be 'merged' into white society, live like white people and perhaps marry white men. ${ }^{81}$ The Board did not seek legislation to enforce a 'no return policy', nor did it dabble in marriage control at the legislative level. If the vociferous debate in the New South Wales Legislative Council on the 1915 amendment (see Chapter 5) was any indication, any legislative measures that sought to control the marriages of Aboriginal women would have been rejected. Russell McGregor argues that the policy of 'breeding out the colour', although widely endorsed and pursued at the national level, was undertaken primarily by 'senior members of the bureaucracy' and not by 'parliament or minister. ${ }^{82}$ Politicians, particularly in the northern states, did not want to be too closely associated with 'absorption' as they came under fire from 'southern welfare bodies and academics' ${ }^{83}$

Even when passed, marriage laws in the 'frontier' administrations although employed - were ineffective. ${ }^{84}$ Chief protector A.O. Neville in Western Australia had the power to stop 'undesirable marriages' but he could not compel 'desirable' ones. The only 'desirable' interracial ones were 'half-caste' women marrying white men and this gender-specific nature of absorption posed insuperable problems. Protector Cecil Cook fared no better in the Northern Territory - in 11 years he achieved fewer than 50 'desirable' marriages. ${ }^{85}$ Although Queensland mirrored the policies of the Northern Territory and Western Australia, after the 1914 appointment of John W. Bleakley as chief protector the state switched to favouring marriages within their own race. Bleakley 'went out of his way to rid Queensland of its mixed-descent population by absorbing it into the Indigenous population rather than the white' ${ }^{86}$ Whether the New South Wales Board was aware of these policies prior to the 1937 Canberra conference of Commonwealth and State Aboriginal Authorities is unclear - the Board minutes and the Board reports show no evidence of any serious discussion of policies employed by other states with the possible exception of Victoria.

81 Haskins, One Bright Spot, 29.

82 McGregor, "'Breed out the Colour”, 288.

83 Austin, 'Cecil Cook, Scientific Thought and "Half-Castes" in the Northern Territory 19271939 ', 115.

84 The term 'frontier administrations' was used by Victoria Haskins in 'A Better Chance?', 50.

85 McGregor, "'Breed out the Colour”, 289.

86 Ellinghaus, 'Absorbing the "Aboriginal Problem”, 200. 
The Board did not develop a policy mechanism to prevent young Aboriginal women from returning to Country after their apprenticeships were complete. It did, however, employ two strategies to pursue its 'no return policy'. First, whenever the girls absconded from their placements the Board was quick to have them apprehended and returned to the same situation, back to Cootamundra or to another placement. Marjorie Woodrow, born in 1922, was taken to Cootamundra Home on the premise that she was 'uncontrollable'. She recalled:

It was hard for me there because my mind was placed elsewhere, to get back to where I belonged. I always had that I must go back to my people ... where my destiny was. I got away a couple of times but got caught and brought back. ${ }^{87}$

Inara Walden states that most girls were caught within a day of absconding and some 'dispatched immediately to another employer' or institutionalised. ${ }^{88}$ The second strategy involved retaining all wages earned during apprenticeship in a trust account managed by the Board. Consequently, the girls had no means of saving money to have any semblance of independence, or funds to return home more easily. Board regulations stipulated the wages for each year of apprenticeship and the employer signed an agreement that required payment in quarterly instalments:

First Year: 1s $6 \mathrm{~d}$ per week with 3 pence as pocket money.

Second Year: 2s $6 \mathrm{~d}$ per week with 6 pence as pocket money.

Third Year: 3s $6 \mathrm{~d}$ per week with 6 pence pocket money.

Fourth Year: 5 s per week with 1 s pocket money ${ }^{89}$

These wages were well under the standard rates for white domestic servants who, in 1910 , received between 10 s and 20 s per week..$^{90}$ Without the advocacy of their employer, the girls were highly unlikely to retrieve any of their money while working as an apprentice and, even with it, there was no guarantee of success. There were some employers who recognised that the Board's tactics. Sydney resident Joan Kingsley-Strack (mentioned in Chapter 5) had several Aboriginal apprentices and in one case she refused to pay her wages to the Board. Kingsley-Strack thought it scandalous that

87 Woodrow, One of the Lost Generation, 13.

88 Walden, 'That Was Slavery Days', 204.

89 Regulation 41 of the Aborigines Protection Act 1909: NSW Government Gazette, No. 92, 8 June 1910 (SLNSW).

90 Walden, 'That Was Slavery Days', 200. 
the girls were refused access to money that was rightfully theirs and were unable to spend it as they wished. Instead, she paid the money directly to her apprentice. ${ }^{91}$ The Board pursued her. Secretary Pettitt wrote:

With reference to the wages of the Aboriginal girl ... in your employ, I beg to draw your attention to the fact that the account is now nearly twelve months in arrears, the account due being $£ 11.2 .9$. I would ask that you give the matter immediate attention, otherwise I shall be reluctantly compelled to place the matter in the hands of the crown solicitor. ${ }^{92}$

Joan Kingsley-Strack was a formidable advocate for justice in this matter and had many influential connections in the Feminist Club, members of the Association for the Protection of Native Races, the Salvation Army and among members of parliament. The fact that the Board had not acted for the previous 12 months perhaps reflected a reluctance to take her on. One of Joan Kingsley-Strack's former apprentices who was now 'free' of the Board, revealed how difficult and intimidating it was for the girls to retrieve their wages even after they had completed their apprenticeships and had returned to their communities. She wrote to Kingsley-Strack:

Pettitt doesn't send it strait through the post to me he sends it to the police and gets them to ask me what I want it for anyone with common sense would know what I want it for only now its my money and I should get it without telling them anything my sister is going to the hospital soon and she has no-one to look after her two little children so I said I would mind them for her. I wanted to write for more money to get a dress for the show but I am two frighten. The policemen said to me Mr Pettitt not boss over you now I am and if you don't get some work I will send you back to the board do you think he can boss me Mrs Strack I'm nearly twenty now don't you send me any money Mrs Strack love all and yourself. ${ }^{93}$

With such restrictive and threatening practices employed by Pettitt and local authorities it was no wonder that the trust fund continued to grow. The Board reported on 31 December 1918 that there were ' 170 girls

91 Letter from Joan Kingsley-Strack to the Board, 4 November 1933, Joan Kingsley-Strack Papers, MS 9551, Series 7, Folder 3, National Library of Australia (hereafter NLA).

92 Letter from Secretary Pettitt to Joan Kingsley-Strack, 8 January 1934, Joan Kingsley-Strack Papers, MS 9551, Series 7, Folder 4 (1933-40) (NLA).

93 Letter from former apprentice to Joan Kingsley-Strack, no date. Joan Kingsley-Strack Papers, MS 9551, Series 7, Folder 4 (1933-40) (NLA). 
in situations, all enjoying the comfort of good homes and learning the general duties of housework, fitting them in time to come to be useful citizens' while the 'amount at deposit with the Board representing wages earned on the 31st December 1918, was $£ 2,77514$ s. 6d'. ${ }^{94}$ For the next 20 years the Board failed to mention this accumulated amount of moneys held in trust in its yearly reports. As noted previously, the Board's overall yearly reporting after 1916 was severely curtailed, but in this case it may well have felt there would be some scrutiny of an ever-increasing fund that was not being dispensed to apprentices as they left the Board's services.

Despite the Board's coercive tactics, its attempts to prevent girls from returning to their communities failed. Legally, the Board had no further control over the girls or the boys once they reached 18 years of age. Walter Henry Childs, chair of the APB from 1929 until 1935, informed Colonel Campbell of the Salvation Army (who was inquiring on behalf of Joan Kingsley-Strack about a girl) that he 'had no jurisdiction ... as she was 18 years old' ${ }^{95}$ The apprentices usually went into service at 14 and finished at 18. The Board did not inform Aboriginal apprentices that their time of service had expired (as witnessed by the Dharawal examples) and treated any appeals by them with 'suspicion and in cases refused to release them'. ${ }^{96}$ Yet, just under half of the girls apprenticed returned to their communities.

By early 1920 the Board recognised that this part of its policy had failed and decided to adjust its approach. Secretary Pettitt sent a Board circular to all managed stations:

I am writing in connection with an aspect of the Board's work which is beginning to create a considerable amount of anxiety, i.e. the disposal of girls who have been out in domestic service for a number of years and have reached a marriageable age ...

94 APBR 1919, 3. Accessed via NSW Legislative Assembly: Aborigines Report of Board for the Aborigines 1915-1922, Q572.991 N (SLNSW).

95 Letter from Joan Kingsley-Strack to Joseph Jackson MLA, October/November 1934, Joan Kingsley-Strack Papers, MS 9551, Series 7, Folder 3 (NLA). There is some confusion surrounding the finishing date. Inara Walden, puts the 'release' age at 21, see 'That Was Slavery Days', 205. This is borne out by the fact that the 1940 amendment to the Aborigines Protection Act 1909 (NSW), which constituted the Aborigines Welfare Board, reduced the completing age of apprenticeships to 18 years; see Section 11(2). Peter Read, however, states that the Board was legally unable to hold them after they were 18, see Read, The Stolen Generations, 15. This is also confirmed by Parliament of New South Wales, Aborigines Protection: Report and Recommendation of the Public Service Board of New South Wales, 4 April 1940 (SRNSW); NSW Parliamentary Papers, Session 1938-40, Vol. 7, 18.

96 Haskins, 'A Better Chance?', 40; Read, The Stolen Generations, 22. 
It is noticed that at the age of 19 or 20 years they naturally become restless and refuse to remain in their situations unless they have a visit home, which is quite natural. They also express a wish to marry and settle down ... It would appear therefore the only solution ... is to allow them upon attaining the age of 20 years to return to the station [to allow] them to marry. This result might very largely be brought about by the sympathy and co-operation of the managers. ${ }^{97}$

Heather Goodall argues that, to a large extent, it was the 'resistance of Aboriginal girls and their families' that forced the change in Board policy. ${ }^{98}$ When the girls were old enough, they were clearly demanding to return home. Also, the issue of Aboriginal girls and marriage began to receive intense media scrutiny in the mid-1920s. Reports claimed that 'Aboriginal girls locked up in private households were being prevented from meeting and marrying potential husbands'. ${ }^{99}$ In 1924 the Sydney Morning Herald alerted its readers with this opening paragraph:

That the aborigines of the State are doomed to extinction we have been told often enough, but, if this be their unfortunate fate, should the processes that are operating towards this end be accelerated by the Aborigines Protection Department itself? The answer, of course, must be no.

It further stated that the 'segregation of the sexes is making it difficult for any more [Aboriginal children] to be born'. It noted that they should not be denied the 'same opportunities for love, courtship, and marriage among their own kind'. It explained to its readers that the girls were taken to Cootamundra for training (usually up to the age of 14) then sent out as domestic servants where they were generally confined to quarters. As a result, the 'matrimonial prospects of these girls are not very bright' and it is not 'creditable to us to have the passing of the race accelerated in this way'. ${ }^{100}$

In the face of criticism, the Board report of 1926 was an admission that it needed to alter its policy to promote marriages back into Aboriginal communities. The Board conceded that 'these young people should not

97 APB Circular No. 1050, 2 June 1920, Copies of Letters Sent 1914-27, 4/7128, Reel 1853

(SRNSW).

98 Goodall, 'Assimilation Begins in the Home', 82.

99 Haskins, 'A Better Chance?', 39.

100 Sydney Morning Herald, 29 October 1924, 12. 
be deprived of the opportunity to marry and settle down' and determined that they should return to their community for a holiday to facilitate 'meeting young people of their own colour'. Under pressure from the girls themselves and the from criticism in the press, the Board had done a complete 'backflip' on its initial policy. The report stated that during the prior 12 months 'over thirty suitable marriages have resulted'. Arrangements were made for the Board's managers 'to take charge of them and to take an interest in their welfare'. ${ }^{101}$

However, placing some of these girls under the supervision of the managers was problematic. Isabel Flick, an Aboriginal woman born in Goondiwindi in 1928, who spent four years at school on the mission at Toomelah, recalled:

There's one thing I remember very clearly. There was a mass wedding, it was about six couples married at once ... you just couldn't fall in love [all at once] there had to be a reason ... As the managers kept changing, some of the girls were more favoured by certain managers and it always makes me think you know ... it's happened in other places where managers have had their fling with the girls ... got afraid that they might be pregnant and so set them up with their mates and married them off. ${ }^{102}$

From her interviews with Aboriginal people in the north-west of the state, Heather Goodall records:

Aboriginal people remember these hastily arranged marriages, some with bemusement, as they recall how as young children they could not understand how so many people could decide to marry all at once, others with bitterness, as they recall their own lives blighted by inappropriate marriages forced on themselves or their loved ones. ${ }^{103}$

Goodall does not see the Board's policy change as a capitulation but rather as another way of achieving the same goal: when the girls returned to their communities, trained in the skills of domestic service, they would become

101 APBR 1926, 3. Accessed via aiatsis.gov.au/sites/default/files/docs/digitised_collections/remove/ 23866.pdf.

102 Flick and Goodall, Isabel Flick, 29-30.

103 Goodall, 'Assimilation Begins in the Home', 83-84. 
the 'trainers of their future nuclear families' and they could help train other Aboriginal women to be, like 'Trojan horses, the bearers of white culture and lifestyle into the heart of Aboriginal families and community life. ${ }^{104}$

However, Robert Donaldson's crusade to ensure that all apprenticed girls would never return was unsustainable. Over half the girls returned to their communities, with many making their own decisions about whom to marry.

\section{A damning legacy}

Arguably, the period between 1916 and 1928 was one of the most destructive and intrusive periods of the Board as it imposed further into the lives of New South Wales Aboriginal communities. It was no coincidence that it occurred after the restructure of the Board in 1916. The new Board, comprised largely of public servants, was less accountable and its agenda was primarily determined by Secretary Pettitt, Inspector Donaldson and Homefinder Miss Lowe. This cabal drove a regime that sought to separate Aboriginal children from their families in the misplaced belief that they would sever their Aboriginal connections and live like white people. It was an attempt to eradicate the Aboriginality of those with less than half an 'admixture of Aboriginal blood': it was an attempt at cultural genocide. Collectively, the Board, and the cabal, saw no worth in Aboriginal culture, family ties, kinship or lore.

The data pertaining to the locations from which Aboriginal children were removed suggests that the Board lacked a considered implementation plan. All Aboriginal children, not just mixed-race children, were targeted. Some large Aboriginal population centres were not among the primary targets, while others were targeted for no obvious reason. In the absence of evidence about inspectors' yearly movements across the state, particularly that of Donaldson over a period of 15 years, there is so far no way of telling, from the written evidence, why some areas became the focus of removals. This muddled picture reflects several things: the arbitrary nature of the Board's implementation of this policy, the Board's lack of oversight and the indifference from Board members. The skewed statistics suggest that Aboriginal communities lived at the whim of the Board's core trio. Their decisions were likely influenced by managers with varying 
degrees of compassion, by local authorities and by the desire to avoid locations that might present more resistance than others. However, it also demonstrates the strength of individual communities to challenge the removal of their children.

There is no doubt that the intent of Board policy was to 'merge' or 'absorb' the lighter-skinned Aboriginal population into the mainstream Australian community while it waited for the 'full-blood' population to die out. The APB's needless removal of thousands of Aboriginal children from their families across New South Wales by the Aborigines Protection Board was cruel and tragic. The trail of apprenticeships of Dharawal children and young adults described above provides a disturbing picture. For many, if not most of the apprentices, the separation from family, the isolation from community, the extreme loneliness, the uncertainty of not knowing why they had been removed and when they could return home, and the abuse that many had no choice but to endure would have been an unbearable burden. For many of the girls, the unwanted sexual attention by males in the household of their employ was an added torment with disastrous consequences. The Board's policy left most of the apprentices isolated and some confused about their Aboriginality, mentally scarred and struggling to resume a normal life. The scale of this tragedy makes the determined resistance by Aboriginal families and the young Aboriginal women who, despite significant hurdles, returned to their communities, even more remarkable. It was small comfort that the Board failed to achieve a key plank in its removal policy. 
This text is taken from Power and Dysfunction: The New South Wales Board for the Protection of Aborigines 1883-1940, by Richard Egan, published 2021 by ANU Press, The Australian National University, Canberra, Australia.

doi.org/10.22459/PD.2021.06 